\title{
Geology and Application of Clays Used in Castellon Ceramic Cluster (NE, Spain)
}

\author{
Sergi Meseguer \\ Unit of Applied Mineralogy, Department of Agrarian Sciences and Environment \\ University Jaume I, Campus de Riu Sec s/n. 12080 CASTELLÓN, Spain \\ Tel: 349-6472-8039Ｅ-mail: smesegue@camn.uji.es \\ Manuel Miguel Jordán (Corresponding author) \\ Department of Agrochemistry and Environment \\ GEA-UMH, University Miguel Hernández
}

Elche. Avda. de la Universidad s/n. 03202 ELCHE Alicante, Spain

Tel: 966-658-416 E-mail: manuel.jordan@umh.es

Francisco Pardo

Unit of Applied Mineralogy, Department of Agrarian Sciences and Environment

University Jaume I, Campus de Riu Sec s/n. 12080 CASTELLÓN, Spain

Tel: 349-6472-8038 E-mail: pardof@guest.uji.es

Teófilo Sanfeliu

Unit of Applied Mineralogy, Department of Agrarian Sciences and Environment

University Jaume I, Campus de Riu Sec s/n. 12080 CASTELLÓN, Spain

Tel: 349-6472-8038 E-mail: sanfeliu@camn.uji.es

Received: October 8, 2010 Accepted: October 26, 2010 doi:10.5539/jgg.v3n1p132

\begin{abstract}
The general characteristics and technological properties of ceramic clays used in the Spanish ceramic cluster (Castellón province), have been investigated. Red clays for ceramic wall tiles and floor tiles are mainly extracted in the Valencian Community, in Villar del Arzobispo, La Yesa, Chulilla, Alcora (Más Vell) and San Juan de Moró, although there is a small proportion coming from Teruel province. An important group of clay raw materials used in the ceramic cluster of Castellón, in Spain, occurs in Permo-Triassic, Cretaceous and Tertiary sediments. These clays are intended for applications in stoneware. Clays were analyzed by X-ray diffraction, chemical composition, particle size distribution, thermal analysis and plasticity. Ceramic bodies were fired at temperatures varying from 850 to $1150^{\circ} \mathrm{C}$ to determine the linear shrinkage, water absorption and flexural rupture strength.
\end{abstract}

Keywords: Ceramic clays, Technological behaviour, Economic geology, Castellón province

\section{Introduction}

The ceramic tile manufacturing process starts with raw materials mining. Most of these raw materials have a mineral nature, and the extractions are usually verified throughout miner tasks on site in the deposit. The quality of the clays which are used in the ceramic process are directly associated with the geologic factors and conditions of the deposits during the sedimentation stages, so the geological knowledge during mining is a basic tool which is involved directly in the quality control.

There is a close relationship between the mineralogical nature of the raw materials used in the ceramic process and the types of ceramic products manufactured. This customization is achieved thanks to the qualitative 
knowledge of the mineral phases which constitute the raw materials used and the mineral dynamics generated on these raw materials when they are subjected to each and every one of the industrial process step (homogenization, humidity, dry, conformation, firing, etc) by which a ceramic piece is generated. A reasonable and suitable mining plan of the ceramic minerals deposit is an excellent way to control the quality of the manufactured products (De la Fuente et al., 1992).

Clay's technological properties are related with their mineralogical composition, physical properties, and with their relative proportions. The knowledge of the mineralogical influence on the technological properties of clays let us improve our understanding about their behaviour and interpret accurately the variations occurring during the mining process in deposits (García-Verduch, 1973).

For instance, the clay's plasticity is one of the most important technological properties which are related to different parameters such as: organic matter content, and the amounts and types of clay minerals present (Worrall et al., 1953). The most disaggregated clay minerals, with major ionic exchange capability are more plastic (Holdridge, 1956). Normally, montmorillonitic minerals are most plastic, then illitics, and finally kaolinitics with a major closed structure. Inside every one of these groups, there exists significant variability of characteristics, depending upon degrees of crystallinity, crystalline structures, particle size distribution and specific surface, with a major capability to absorb water (Galan et al., 1974).

A significant body of literature exists on ceramic clay mineralogy and geochemistry. It is well known that industrial clays have a complex mineralogical composition, which makes the study of mineral phases present in the raw material, rather difficult. A series of transformations controlling the final properties of the ceramic products occur during the firing process of phyllosilicates and accompanying minerals like quartz, feldspar, calcite, dolomite and hematite (Gonzalez-Garcia et al., 1990 and Jordán et al., 1999, 2001). Through the ceramic process, once the crystalline structures of these minerals exceed their stability limits, they are partially decomposed while simultaneously others are being formed. The destruction of the pre-existing structure does not occur instantaneously (Jordán et al., 2008). The knowledge of the origin, diagenesis and physicochemical composition of the clays is essential in order to search suitable compositions when these are required for ceramic production (Sanfeliu, 1987 and Sanfeliu and Jordán. 2009).

Clay's properties are controlled by clay mineral proportion, mineral type, and chemical composition. Although, is very difficult to evaluate this influence in a quantitative way due to their complex and variables structures that largely determine their behaviour. So, the geological background conditionate all of these parameters (Weaver et al., 1973).

The main objective of this study is the knowledge of composition and technological behaviour of clays. They are the main raw materials used in the ceramic cluster of Castellón. The best understanding of clays: composition, mineralogy, texture, it can optimize the ceramic process. The positive results obtained in this set of preliminary tests lead us to envisage new research programs in Spain, focused on testing other raw materials on a semi-industrial scale, assessing the effective possibility of using them as ceramic raw materials in the local ceramic industry.

\section{Castellon ceramic cluster}

The tile and clay pavement industry is basically mainly located in the province of Castellón, in Spain. Nowadays, more than $50 \%$ of its production is exported. The manufacture of wall tiles, floor tiles and ceramic coating uses red clays as raw materials. The white body clays or ball-clays hardly reach $5 \%$ of the total amount. Other raw materials are also consumed used, such as kaolin, calcined clays, feldspars, siliceous sand, mineral pigments, etc, which are not going to be considered in this article. The focus of this paper is developed on a very prestigious sector at an international level, ranking on the top four as a world-wide producer. The production and sales data from 2003 to 2008 are shown in Table 1. In addition, in the Table 2 is showed the ceramic tile Spanish production typology (Note 1) (Note 2).

There are two types of clays consumed in this sector: red clays and white or ball clays. In order to reach the proper homogeneity, purity and particle size to get the final product quality, the previous preliminary treatment of the clays is necessary in the manufacture process. Two treatments are used:

i) a dry-via, or grinding without adding water

ii) humid-via or atomization.

The dry-via process is more frequent among Catalan companies which manufacture ceramic products processed by extrusion (face bricks, tiles), while those located in Castellón mainly use atomization processes. Atomization processes consist of pulverizing the clay suspended in water against a warm air flood. The result is microscopic 
spheres of clays filled with air, which are very appropriate for the dry pressing of floor tiles.(Note 3)

\section{Red clays from Castellon ceramic cluster}

The distribution of the main clay raw materials used in the ceramic industry in Castellon is shown in the Figure 2 as well as their classification in the Table 2. These clayish materials come from deposits of Castellón, Valencia, and Teruel provinces, and belong mostly to Permo-Triassic sediments, specifically to Saxonian and Buntsandstein facies, Cretaceous sediments of the Weald and Utrillas facies, and Tertiary sediments from Neogen (Sanfeliu, 1991, 1999). (Note 4)

The main feature of these clays and in general of all the sedimentary deposits is the heterogeneity of its mineralogy. This fact leads considerable variability of their properties at the production level. Such inconvenience can be minimized by using the homogenization systems carried out in the mine exploitations themselves, in the atomizers or in the manufacturing companies. In general, such systems consist of building up piles (backlogs) of horizontal layers made up of materials of various qualities coming from different exploitation areas (Meseguer et al., 2007). (Note 5)

The importance of these raw materials is their relatively proximity to the manufacturing centres, presenting as a common characteristic a high level in iron oxide content, incorporated in the mineral structure of the hematite. Consequently, these raw materials are used for manufacturing red ceramic tiles (Meseguer et al., 2007). The classification of these red clays is based on their cronostratigraphical origin and also their carbonate content, which is linked to the geological background of each deposit. (Table 3) (Note 6)

\section{Experimental}

The main deposits of red clays used in the formulation of ceramic pastes in Castellon ceramic cluster have been selected. Raw materials, 50 samples for each deposit, were oven-dried at $110^{\circ} \mathrm{C}$ until constant weight. They were then ground with a hammer mill to null residue in the 630 micron control sieve, following normal practice in ceramic laboratories (Meseguer et al., 2009a).

The mineralogical analysis was carried out using a Siemens D-5000 diffractometer, $\mathrm{CuK} \alpha$ radiation, both on powder (bulk samples) and oriented aggregates (natural and treated with ethylene glycol and heated to $550^{\circ} \mathrm{C}$ for $2 \mathrm{~h}$ ).

The chemical analysis was obtained by X- ray fluorescence (Bruker S4 Pioneer) using the conventional techniques (Meseguer et al., 2009b). CaCO3 content was determinated by calcimetry (Bernard method).

The Pfefferkon method was used for determined the plasticity index (PI). After moistening to obtain a shaping paste, the drying capacity of the clays was determined by using a barelattograph to trace the Bigot curve.

To simulate industrial pressing conditions, the clays were moistened by hand, mixed sufficiently and sieved (1 $\mathrm{mm}$ ) until homogeneous agglometates were obtained with $6 \%$ water, left to rest for $24 \mathrm{~h}$ and then pressed (250 $\mathrm{Kg} / \mathrm{cm}^{2}, 80 \times 40 \times 5 \mathrm{~mm}$ ) by using a laboratory press.

Finally, we have to take into account that there is a $15 \%$ loss during the manufacturing process due to the evaporation of the natural water and the loss of ignition.

\section{Results and discussion}

Clays can be classified depending on its $\mathrm{CaCO} 3$ content (Table 3). Table 4 shows the chemical composition of bulk samples of the deposits studied. The purpose for this was to be able to process the maximum amount of data possible in the statistical treatment of the samples.

The chemical composition (Table 4) of the samples shows a high iron content in Moró and Villar clays (> 7\%), responsible for the reddish colour developed upon firing. However, the iron content in calcareous clays is low (around $4 \%$ ). Moró and Chulilla clay samples show the highest relative amount of alkalis $\left(\mathrm{Na}_{2} \mathrm{O}+\mathrm{K}_{2} \mathrm{O}\right)$, explaining why this sample matures at relatively low temperatures. By contrast, the higher amount of carbonates in Mas Vell. Sitjar and Araya clay samples might explain the delay in the sintering process. Decarbonation is a strongly endothermic reaction that generates a high volume of gas, leading expansive reactions (Cultrone et al., 2004). (Note 7)

Table 5 and 6 shows the mineralogical composition of the clay samples and their ceramic characterization. (Note 8) (Note 9)

The Tertiary clays of the province of Castellón have a mineralogical composition which, shows the presence of kaolinite, chlorite and some interstratified elements in varying quantities. Other mineral phases are: montmorillonite, quartz, gypsum, calcite and feldspars. The clay fraction is made up of illite and/or kaolinite 
and/or chlorite and/or interstratified elements. Its mineralogical and chemical composition controls its technological properties, which in turn determine its use in manufacturing porous products (Carretero et al., 2002). "Arcilla de Moró" is the commercial name for one of the most widely used clays since the 70s (Jordan et al., 2009). It was initially used for manufacturing bricks and then for manufacturing ceramic tile bodies. An essential aspect related to this raw material is the nearness of the exploitations to the manufacturing centres. This fact represents an added advantage not only with respect to the other raw materials of the same characteristics, whether those in Villar del Arzobispo (Valencia) or in Galve (Teruel), but also to new raw materials such as the clay from Morella (Castellón). From a ceramic point of view, the "arcilla del Moró" is classified as a low carbonate content raw material $(<5 \%)$, mainly used in the press manufacturing of red paste glazed stoneware. These raw materials belong to Upper-Permic (Sanfeliu et al., 1987). The association of minerals of the clay typical of the inferior unit and of the "arcilla de Moró" is made up of illite \pm kaolinite \pm chlorite $\pm \mathrm{I} / \mathrm{S} \pm \mathrm{K} / \mathrm{S}$.

The clay from Morella shows the following mineralogical composition: quartz (33\%), illite (14\%), sodium feldspar (7\%), potassium feldspar (3\%), hematite (7\%), chlorite (3\%) and calcite (Table 5). The technological properties of the red clays from Morella make it being very suitable for manufacturing low-porosity products -such as glazed stoneware. The balance of properties - plasticity-unfloculability-pressibility- is optimum (Sánchez et al., 2005). (Note 10)

\section{Conclusions}

As we can appreciate by mineralogy and geochemical characterization, deposits show an important heterogeneity; this fact leads to an important variability of the properties in the different materials and products. Such inconvenience has been minimized by using the homogenization systems carried out in the mine exploitations themselves, in the atomizers or in the manufacturing companies. In general, such systems consist of building up piles (backlogs) of horizontal layers made up of materials of various qualities coming from different exploitation areas.

Red clays have in general an illitic-kaolinitic nature with medium or high iron oxide content, on average higher than 3\% (in weight). All studied clays seem to be easily adaptable to a correct dry pressing ceramic process. In particular, illite-kaolinite-rich samples shows the best mechanical behaviour.

The more suitable application for the Tertiary clays of the province of Castellón woud be associated to manufacture porous products. The technological properties of the red clays from Morella, Villar, or Galve make these raw materials more appropriate for manufacturing low-porosity products -glazed stoneware.

\section{References}

Carretero. M.I., Dondi. M., Fabbri. B. \& Raimondo. M. (2002). The influence of shaping and firing technology on ceramic properties of calcareous and non-calcareous illitic-chloritic clays. Applied Clay Science, 20, 301-306. doi:10.1016/S0169-1317(01)00076-X, http://dx.doi.org/10.1016/S0169-1317(01)00076-X

Cultrone, G., Sebasti'n. E., Elerk. K., De la Torre, M.J., Cazalla, O. \& Rodriguez-Navarro, C. (2004). Influence of mineralogy and firing temperature on the porosity of bricks. Journal of the European Ceramic Society, 24, 547-564. doi:10.1016/S0955-2219(03)00249-8, http://dx.doi.org/10.1016/S0955-2219(03)00249-8

De la Fuente, C. Boix, A. \& Sanfeliu, T. (1992). La investigación mineralógica en las materias primas cerámicas. Técnica Cerámica, 207, 660-670.

Galan, E \& Espinosa de los Monteros, F. (1974). El caolín en España. Sociedad Española de Cerámica y Vidrio. $350 \mathrm{pp}$.

García-Verduch, A. (1973). Algunos aspectos de la investigación cerámica actual. Bol. Soc. Esp. Ceram, 12(5), 279-288.

González-García, F., Romero-Acosta, V., García Ramos, G. \& González Rodríguez, M. (1990). Firing transformations of mixtures of clays containing illite, kaolinite and calcium carbonate used by ornamental tile industries. Applied Clay Sciences, 5, 361-375. doi:10.1016/0169-1317(90)90031-J, http://dx.doi.org/10.1016/0169-1317(90)90031-J

Holdridge D. A. (1956). Ball clays and their properties. Trans. Brit. Journ. Ceram. Soc, 55(6), 369-379.

Jordán M. M., Montero M. A., Meseguer S. \& Sanfeliu T. (2008). Influence of firing temperature and mineralogical composition on bending strengh and porosity of ceramic tile bodies. Applied Clay Science, 42, 266-271. doi:10.1016/j.clay.2008.01.005, http://dx.doi.org/10.1016/j.clay.2008.01.005

Jordán, M. M., Boix, A., Sanfeliu, T. \& de la Fuente, C. (1999). Firing transformations of cretaceous clays used 
in the manufacturing of ceramic tiles. Applied Clay Science, 14, 225-234. doi:10.1016/S0169-1317(98)00052-0, http://dx.doi.org/10.1016/S0169-1317(98)00052-0

Jordan, M. M., Martín-Martín. J. D., Sanfeliu, T., Gómez-Gras, D. \& De la Fuente, C. (2009). Mineralogy and firing transformations of Permo-Triassic clays used in the manufacturing of ceramic tile bodies. Applied Clay Science, 44, 173-177. doi:10.1016/j.clay.2009.01.018, http://dx.doi.org/10.1016/j.clay.2009.01.018

Jordán, M. M., Sanfeliu, T. \& De la Fuente, C (2001). Firing transformations of Tertiary clays used in the manufacturing of ceramic tile bodies. Applied Clay Science, 20, 87-95. doi:10.1016/S0169-1317(00)00044-2, http://dx.doi.org/10.1016/S0169-1317(00)00044-2

Meseguer S, Jordan M. M. \& Sanfeliu, T. (2007). Economic Geology of the ceramic clays in Castellon, Spain. In: Digging Deeper. Proceedings of the Ninth Biennal SGA Meeting, 2, 815-818. Cambridge Mineral Resources plc. Navan, Ireland.

Meseguer, S., Jordan, M. M., \& Sanfeliu, T. (2009a). Use of mine spoils from Teruel coal mining district. Environmental Geology, 56, 845-853. doi:10.1007/s00254-007-1185-9, http://dx.doi.org/10.1007/s00254-007-1185-9

Meseguer, S., Sanfeliu, T. \& Jordan, M. M. (2009b). Classification and statistical analysis of mine spoils chemical composition from Oliete Basin (Teruel. NE Spain). Environmental Geology, 56, 1461-1466. doi:10.1007/s00254-008-1241-0, http://dx.doi.org/10.1007/s00254-008-1241-0

Sánchez, E., García-Ten, J., Quereda, P. \& Beltrán, V. (2005). Arcilla de Morella. Nueva materia prima para la fabricación de baldosas cerámicas de pasta roja. Técnica Cerámica, 298, 1386-1396.

Sanfeliu T. (1991). Mineralogía de arcillas cerámicas terciarias de Castellón. Diputación Provincial de Castellón. Colección Ciencias. 315p.

Sanfeliu, T. \& Jordan, M. M. (2009). Geological and environmental management of ceramic clay quarries: a review. Environmental Geology, 57, 1613-1618. doi:10.1007/s00254-008-1436-4, http://dx.doi.org/10.1007/s00254-008-1436-4

Sanfeliu, T. \& Martín Martín, J. D. (1999). Estructura y litoestratigrafía, en: La Provincia de Castellón, Servicio de Publicaciones de la Diputació de Castelló, Castelló, 31-40.

Sanfeliu, T., De la Fuente, C., Martinez, S. \& Queralt, I. (1987). Materias primas y recursos naturales de Castellón. I: Yacimientos de arcillas de interés cerámico. Veliuny Ricerche Montanar Editore.

Vera, J. A. (2004). Geología de España. Instituto Geológico y Minero de España.

Weaver, C. E. \& Pollard. (1973). The chemistry of clay minerals (Developments in Sedimentology, $\mathrm{n}^{\circ} 15$ ). Elsevier, Scientific Publ. Co., Amsterdam.

Worrall, W \& Green, C. V. (1953). The organic matter in clays. Trans. Jour. Brit. Ceram. Soc., 55(6), 369-379.

\section{Notes}

Note 1. Production and sales of the Castellon ceramic tile industry (Spain). Sales in million $€$ and production in million $\mathrm{m}^{2}$. Source: Ascer.

Note 2. Spanish production typology $\left(\mathrm{x} 1000 \mathrm{~m}^{2}\right)$. Source: Ascer.

Note 3. Ceramic tile manufacturing process (source ASCER).

Note 4. Geographical distribution of the main exploitations of the red clays used in the Castellon ceramic cluster.

Note 5. Geological background of the main quarries, setting in the south-oriental portion of the Iberian mountain range (source Vera, J.A.-IGME, 2004).

Note 6. Classification of the main raw materials for red-coloured substrate used in the ceramic industry of Castellón. Castellón (Cs), Valencia (V) and Teruel (Te).

Note 7. Chemical composition (\% weight) of main Red-clays used in the ceramic industry of Castellón.

Note 8. Mineralogical composition (\% weight) of main Red-clays used in the ceramic industry of Castellón.

Note 9. Ceramic characterization of some of the main Red-Clays used in the ceramic industry of Castellón. Legend: * Pfefferkorn; ** pressure $250 \mathrm{~kg} / \mathrm{cm}^{2}$

Note 10. Permo-triassic clay deposit from Sant Joan de Moró, Castellón. 
Table 1. Production and sales of the Castellon ceramic tile industry (Spain). Sales in million $€$ and production in million $\mathrm{m}^{2}$ (Source: Ascer.)

\begin{tabular}{|c|c|c|c|c|c|c|}
\hline & 2003 & 2004 & 2005 & 2006 & 2007 & $2008^{*}$ \\
\hline Production & 583.4 & 595.5 & 609.2 & 608.4 & 584.7 & 494.7 \\
\hline Domestic sales & 1,379 & 1,5 & 1,609 & 1,799 & 1,871 & 1,46 \\
\hline Exports & 1,939 & 1,977 & 2,041 & 2,183 & 2,295 & 2,211 \\
\hline Total sales & 3,318 & 3,477 & 3,65 & 3,982 & 4,166 & 3,671 \\
\hline
\end{tabular}

Table 2. Spanish production typology (x 1000 $\mathrm{m}^{2}$ ) (Source: Ascer.)

\begin{tabular}{|c|r|r|r|c|c|c|}
\hline Production & \multicolumn{1}{|c|}{2002} & \multicolumn{1}{|c|}{2003} & 2004 & 2005 & 2006 & 2007 \\
\hline Extruded & 19.073 & 18.955 & 19.482 & 19.800 & 19.924 & 20.900 \\
\hline \% total production & $3,1 \%$ & $3,2 \%$ & $3,3 \%$ & $3,3 \%$ & $3,3 \%$ & $3,6 \%$ \\
\hline Porcelain tiles & 48.187 & 59.527 & 73.964 & 94.675 & 113.534 & 116.207 \\
\hline \% total production & $8,0 \%$ & $10,2 \%$ & $12,4 \%$ & $15,5 \%$ & $18,7 \%$ & $19,9 \%$ \\
\hline Wall tiles & 236.324 & 233.356 & 234.989 & 238.132 & 242.054 & 239.956 \\
\hline \% total production & $49,9 \%$ & $40 \%$ & $39,5 \%$ & $39,1 \%$ & $39,8 \%$ & $41 \%$ \\
\hline Glazed floor tiles & 302.116 & 271.562 & 267.066 & 256.593 & 232.887 & 207.637 \\
\hline \% total production & $49,9 \%$ & $46,5 \%$ & $44,8 \%$ & $42,1 \%$ & $38,3 \%$ & $35,5 \%$ \\
\hline Red body clays & 493.370 & 458.775 & 453.349 & 447.794 & 431.458 & 400.552 \\
\hline \% total porcelain tiles & $81,5 \%$ & $78,6 \%$ & $76,1 \%$ & $73,5 \%$ & $70,9 \%$ & $68,5 \%$ \\
\hline Ball clays or white body clays & 112.330 & 124.625 & 142.151 & 161.406 & 176.942 & 184.148 \\
\hline \% total production & $18,5 \%$ & $21,4 \%$ & $23,9 \%$ & $26,5 \%$ & $29,1 \%$ & $31,5 \%$ \\
\hline
\end{tabular}

Table 3. Classification of the main raw materials for red-coloured substrate used in the ceramic industry of Castellón. Castellón (Cs), Valencia (V) and Teruel (Te)

\begin{tabular}{|c|l|l|l|l|}
\hline \multirow{2}{*}{ DENOMINATION } & \multirow{2}{*}{$\begin{array}{c}\text { ORIGIN } \\
\text { weight }\end{array}$} & \multicolumn{2}{|c|}{ Tertiary } \\
\cline { 3 - 5 } & & Permo triassic & Cretaceous & \\
\hline $\begin{array}{c}\text { Low carbonate content } \\
\text { clays }\end{array}$ & $<5$ & $\begin{array}{l}\text { Sant Joan de } \\
\text { Moró (Cs) }\end{array}$ & $\begin{array}{l}\text { Morella (Cs) Villar (V) Higueruelas } \\
\text { La Yesa (V) Galve (Te) }\end{array}$ & \\
\hline $\begin{array}{c}\text { Medium carbonate } \\
\text { content clays }\end{array}$ & $5-15$ & Chulilla (V) & $\begin{array}{c}\text { Mas Vell Sitjar } \\
\text { Araia (Cs) }\end{array}$ \\
\hline $\begin{array}{c}\text { High carbonate content } \\
\text { clays }\end{array}$ & $>15$ & & & \\
\hline
\end{tabular}


Table 4. Chemical composition (\% weight) of main Red-clays used in the ceramic industry of Castellón

\begin{tabular}{|c|c|c|c|c|c|c|c|c|c|}
\hline Red Clay & $\mathrm{SiO}_{2}$ & $\mathrm{Al}_{2} \mathrm{O}_{3}$ & $\mathrm{Fe}_{2} \mathrm{O}_{3}$ & $\mathrm{CaO}$ & $\mathrm{MgO}$ & $\mathrm{Na}_{2} \mathrm{O}$ & $\mathrm{K}_{2} \mathrm{O}$ & $\mathrm{TiO}_{2}$ & L.O.I. \\
\hline Moró & 60,2 & 19,2 & 7,69 & 1,79 & 0,84 & 0,35 & 4,95 & 0,85 & 4,6 \\
\hline Villar & 57,5 & 21,9 & 7,66 & 0,62 & 1,44 & 0,44 & 3,55 & 1,09 & 6,3 \\
\hline Galve & 59,4 & 23 & 5,98 & 1,24 & 1,19 & 0,24 & 3,41 & 0,62 & 5,6 \\
\hline Chulilla & 54,7 & 20,1 & 6,41 & 2,41 & 2,85 & 0,14 & 4,65 & 0,94 & 7,8 \\
\hline Mas Vell & 43,7 & 15 & 4,84 & 13,2 & 2,5 & 0,26 & 4,48 & 0,56 & 15 \\
\hline Sitjar & 31,1 & 13,4 & 4,39 & 23,6 & 1,36 & 0,2 & 3,67 & 0,26 & 21,7 \\
\hline Araya & 31,1 & 14,3 & 4,24 & 22,8 & 1,72 & 0,16 & 3,83 & 0,62 & 21,8 \\
\hline
\end{tabular}

Table 5. Mineralogical composition (\% weight) of main Red-clays used in the ceramic industry of Castellón

\begin{tabular}{|c|c|c|c|c|c|c|c|c|}
\hline \multirow{2}{*}{ Red Clay } & \multirow{2}{*}{ Kaolinite } & \multirow{2}{*}{ Illite } & \multirow{2}{*}{ Quartz } & \multirow{2}{*}{ Carbonates } & \multirow{2}{*}{ Feldspars } & Fe\&Ti & \multirow{2}{*}{ Chlorite } & \multirow{2}{*}{ Others } \\
\hline & & & & & & compounds & & \\
\hline Moró & 18 & 26 & 42 & 4 & 2 & 7 & - & 1 \\
\hline Villar & 19 & 22 & 39 & 3 & 8 & 7 & - & 2 \\
\hline Galve & 22 & 21 & 35 & 3 & 8 & 7 & 3 & 1 \\
\hline Chulilla & 10 & 24 & 34 & 11 & 8 & 6 & 5 & 1 \\
\hline Mas Vell & 10 & 18 & 28 & 31 & 8 & 4 & - & 1 \\
\hline Morella & 15 & 14 & 33 & 3 & 10 & 7 & 3 & - \\
\hline
\end{tabular}

Table 6. Ceramic characterization of some of the main Red-Clays used in the ceramic industry of Castellón. Legend: * Pfefferkorn; ** pressure $250 \mathrm{~kg} / \mathrm{cm}^{2}$

\begin{tabular}{|l|c|c|c|c|}
\hline \multicolumn{1}{|c|}{ CLAY TYPE } & $\begin{array}{c}\text { Upper fraction } 63 \mu \mathrm{m} \\
(\%)\end{array}$ & Plasticity* & LC1150 & $\begin{array}{l}\text { Apparent } \\
\text { Density** }\end{array}$ \\
\hline MORÓ & 7,5 & $14-16$ & 3,5 & 2,14 \\
\hline MADROÑO & 3 & $20-23$ & 7,5 & 1,99 \\
\hline GALVE & 4,5 & $21-22$ & 5,7 & 2,04 \\
\hline MORELLA & 6 & $18-19$ & 6 & 1,98 \\
\hline LA YESA fundente & 2 & 23 & 8,5 & 1,93 \\
\hline LA YESA refractaria & 4,5 & 19 & 2,9 & 2,02 \\
\hline CAMPILLO (Mas vell) & 6 & $18-20$ & 1,5 & 1,95 \\
\hline
\end{tabular}




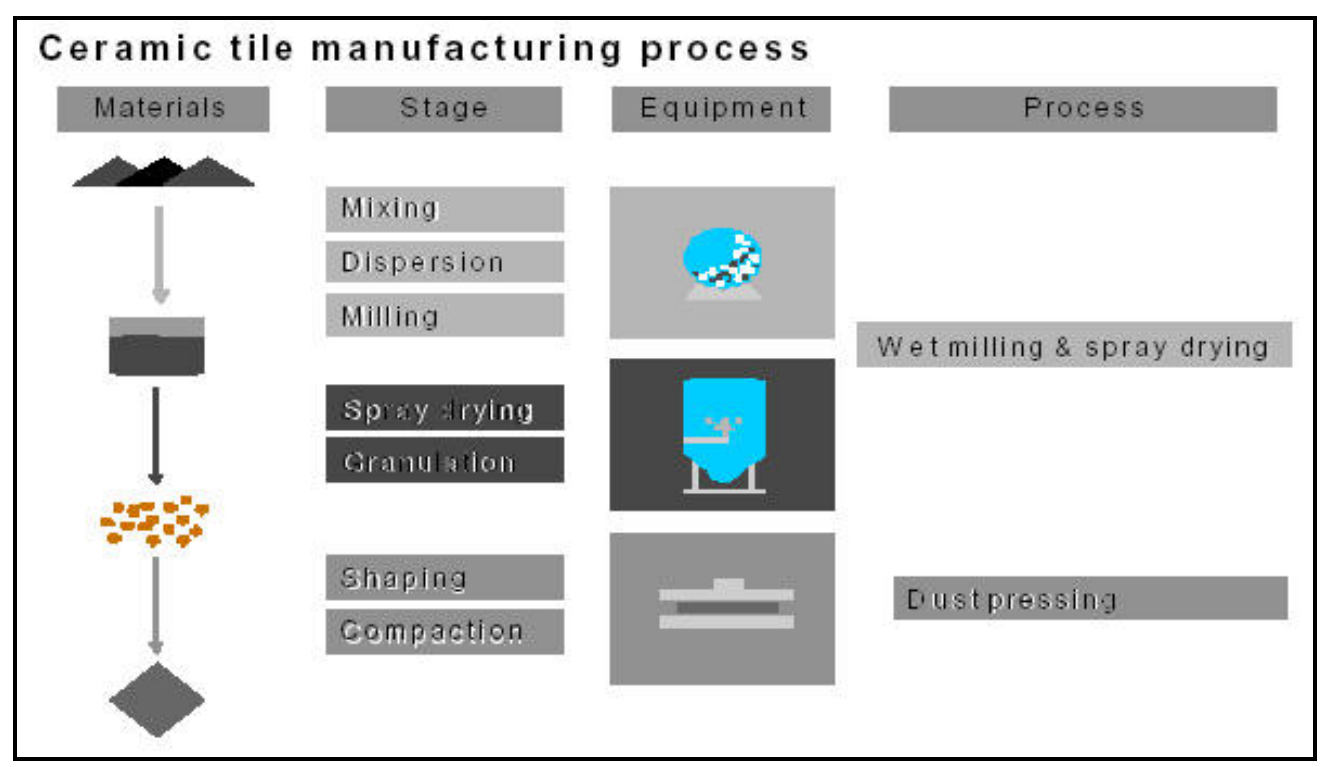

Figure 1. Ceramic tile manufacturing process (Source: ASCER)

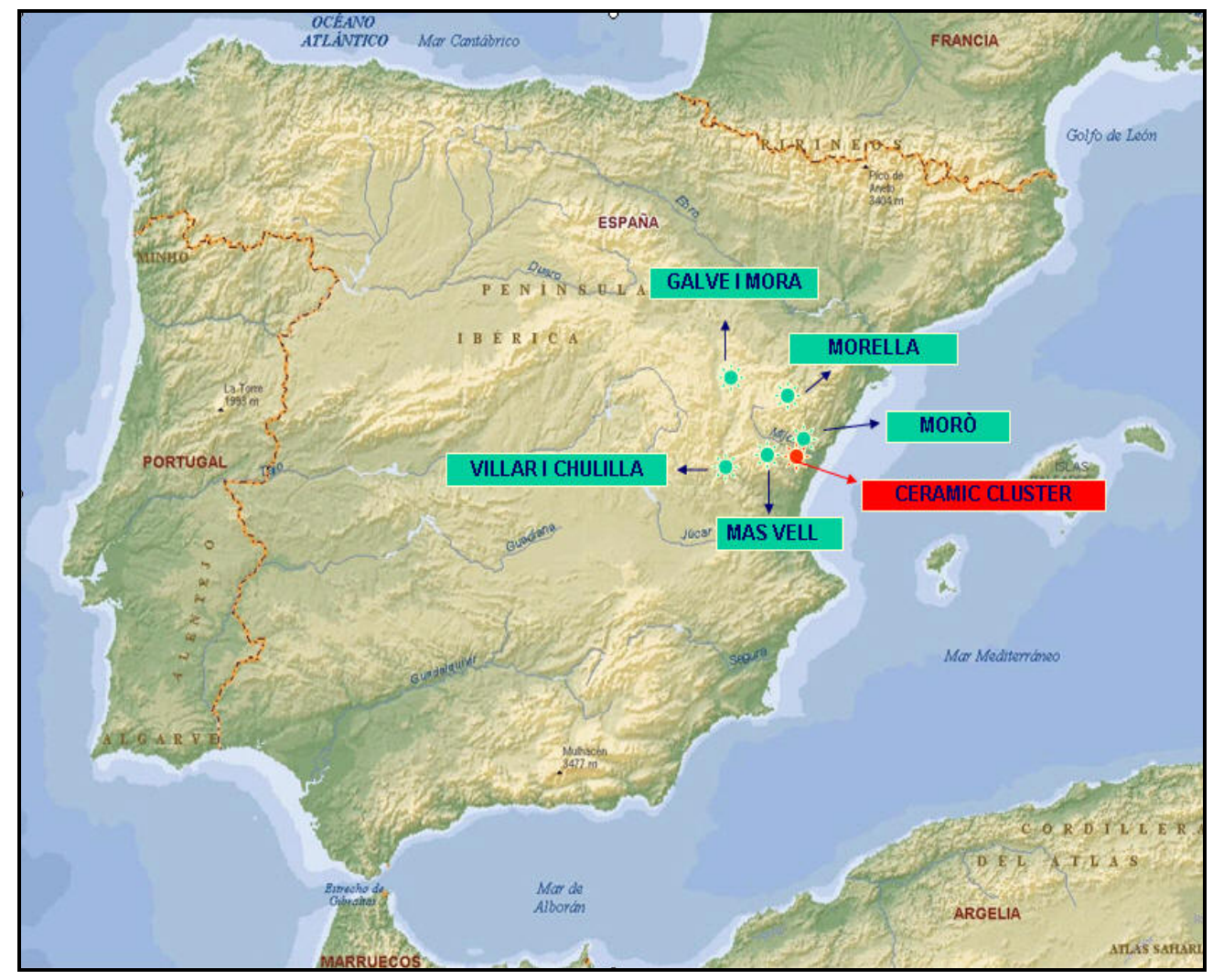

Figure 2. Geographical distribution of the main exploitations of the red clays used in the Castellon ceramic cluster 


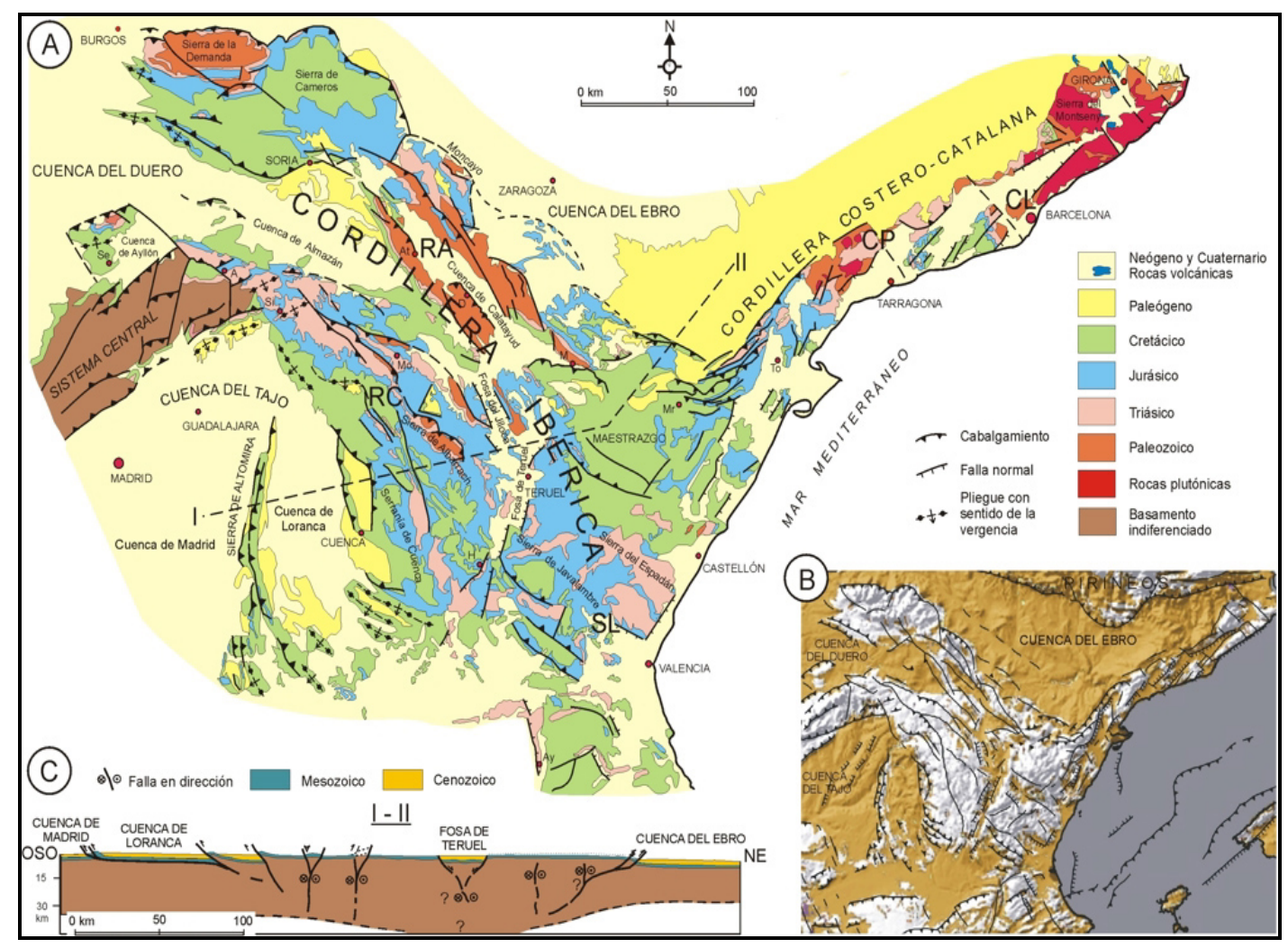

Figure 3. Geological background of the main quarries, setting in the south-oriental portion of the Iberian mountain range (Source: Vera, J.A.-IGME, 2004)

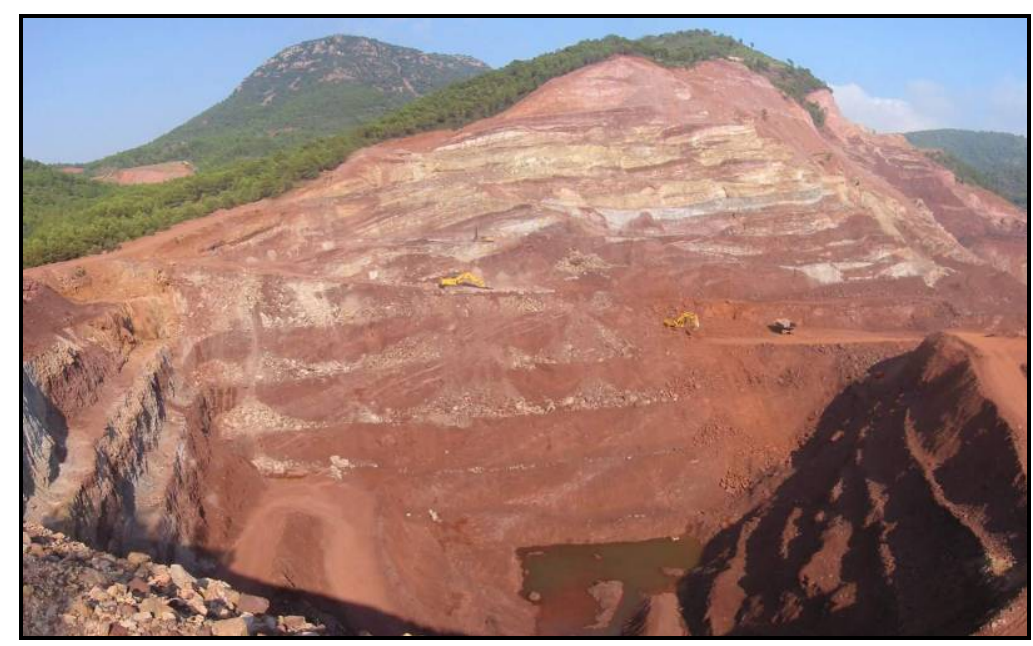

Figure 4. Permo-triassic clay deposit from Sant Joan de Moró, Castellón 